\title{
The Chemical Analysis of Propolis, Which are Produced in Western of Turkey
}

\section{Türkiye'nin Batısında Üretilen Propolislerin Kimyasal Analizi}

\author{
Research Article
}

\section{Aslı Özkök ${ }^{1 *}$, Kadriye Sorkun ${ }^{1,2}$, Bekir Salih ${ }^{3}$}

'Hacettepe University, Faculty of Science, Bee and Bee Products Research and Application Center, Beytepe, Ankara, Turkey. ${ }^{2}$ Hacettepe University, Faculty of Science, Biology Department, Beytepe, Ankara, Turkey.

${ }^{3}$ Hacettepe University, Faculty of Science, Chemistry Department, Beytepe, Ankara, Turkey.

\section{A B S TR ACT}

ropolis or bee glue is a natural product that contains numerous fairly strong chemical compounds and it is important for people health. But propolis collecting area and collecting time are very important for the product quality. For this purpose, this study conducted in the region of Muğla city in western of Turkey and propolis features uncovered. 27 propolis samples were collected from nine areas of the Muğla city in western of Turkey where honeydew beekeeping is practiced extensively, from September to November. GC-MS chemical substance analyses of 27 propolis samples revealed many chemicals including alcohols, aromatic alcohols, linear aldehydes, flavanones, linear hydrocarbons, linear acid esters, aromatic acids, aromatic esters, aromatic acid esters, aliphatic carboxilic acids, aliphatic carboxilic acid esters, aliphatic esters and other chemical substances. Propolis concentration changed between $0.71 \%$ and $13 \%$. according to the amount of propolis used.

\section{Key Words}

Propolis, GC-MS analysis, chemical compounds.

\section{ÖZET}

ropolis veya arı zamkı farklı kimyasal özellikte bileşikler ve mineral maddeler içeren oldukça kompleks bir yapıya sahip doğal bir üründür ve insan sağlığı için önemlidir. Fakat propolisin toplama alanı ve zamanı ürün kalitesi için oldukça önemlidir. Bu amaçla bu çalışmada Türkiye'nin batısında bulunan Muğla ilinde üretilen propolislerin özellikleri ortaya çıkarılmıştır. Çam balı arıcılığının yoğun olarak yapıldığı Muğla ilinin 9 noktasından Eylül ayından Kasım ayına kadar 27 propolis örneği toplanmıştır. 27 adet propolis örneğinin GC-MS ile kimyasal madde tayini sonucunda, alkoller, aromatik alkoller, düz zincirli aldehitler, flavanonlar, düz zinzirli hidrokarbonlar, aromatik hidrokarbonlar, düz zincirli asit esterleri, aromatik asitler, aromatik esterler, aromatik asit esterleri, alifatik karboksilik asitler, alifatik karboksilik asit esterleri, alifatik esterler ve diğer kimyasal maddeler tespit edilmiştir. Propolis derişimleri, kullanılan propolis miktarına bağlı olarak \% 0.71 ile \% 13 arasında değişmiştir

\section{Anahtar Kelimeler}

Propolis, GC-MS analizi, kimyasal bileşenler.

Article History: Received: Feb 29, 2016; Revised: May 17, 2016; Accepted: Jun 20, 2016; Available Online: Jul $31,2016$.

DOI: 10.15671/HJBC.20164420575

Correspondence to: A. Özkök, Hacettepe University, Faculty of Science, Bee and Bee Products Research and Application Center, Beytepe, Ankara, Turkey. 


\section{INTRODUCTION}

Dropolis or bee glue is a chemically complex resinous mixture collected by Apis mellifera bees from different parts of plants [1]. It is a resinous material prepared by honeybees (Apis mellifera L.) using beeswax and plant exudates. Bees generally use propolis as a construction material for sealing openings and cracks within the beehive [2].

Propolis is a sticky substance having colors from dark-brown to yellow with respect to its origin. It is a resinous and waxy substance collected from the buds and bark of trees by honeybees [3]

Propolis has become a popular ingredient in complementary healthcare, and the use of this natural material in pharmaceutical and food preparations is growing due to its wide range of therapeutic properties including; antimicrobial, anti-oxidant, anti-inflammatory, immunomodulatory and anticancer activities [4-6]. Some of the scientists show biological properties, including antibacterial effect against antibiotic-resistant human pathogenic bacteria [7-10] and canine pathogenic bacteria [11] antifungal activity against dermatophytes and yeasts $[12,13]$, free radical scavenging and antimutagenic activities $[9,14,15]$. In the last few years, several in vitro and in vivo studies have also shown antitumoural activity of propolis from different geographic origin and of some of its isolated compounds on various tumour and non-tumour cells [16-21]. Briefly, this natural product can block specific oncogenic signalling pathways (e.g. $\beta$-catenin, c-myc, NF-kB and some intermediary of the PI3K/AKT pathway), which in turn leads to a decrease in cell proliferation and growth and can also act by decreasing the cancer stem cell population, increasing apoptosis, exerting antiangiogenic effects and modulating the tumour microenvironment, more specifically suppressing the invasion and migration [17]. Results obtained so far allow to confirm the various propolis biological properties as well as its safety, increasing the interest in the use of propolis as a functional food and nutraceutical that may provide a health benefit [22].
The chemical composition of propolis is known to be complex and variable between seasons and regions [23]. Numerous factors, such as the floristic composition of the area, location and time of collection impact on the chemical composition of propolis [24]. Propolis samples analysed from various parts of the world have been collectively reported to contain over 300 different chemical compounds, including polyphenols, esters of phenolic acids, flavonoids, sesquiterpenes, diterpenes, triterpenes, lignans, prenylated benzophenones, aldehydes, steroids and coumarins [25,26]. Phenolics (mostly flavonoids) constitute over $50 \%$ of the total weight of propolis [27].

Different types of propolis have been reported according to the geographical area of production, botanical source and chemical composition. Generally, propolis is composed of resin, wax, essential oils, pollen and other substances and it includes minerals and organic compounds like phenolic acids or their esters, flavonoids, terpenes, aromatic aldehydes and alcohols, fatty acids, stilbenes and $\beta$-steroids [28]. Nevertheless, the standardization of the chemical composition of propolis is difficult since it depends on the plant sources and on the geographical and climatic conditions of the site of collection [28, 29] and hence, metabolite profiling of propolis is a valuable tool to standardise as well as provide a chemical signature for a chemotype that may have superior health benefits [30].

In Turkey, Sorkun and Bozcuk [31] published the first report on propolis. Subsequently, a lot of studies related to propolis in Turkey were published [32-35]. Also Some Turkish studies on the anti-oxidant, antimicrobial and antiinflammatory activities of propolis have been documented [8,36-39].

In this study we would like to find chemical compounds of propolis from western of Turkey. Especially Muğla is important place for beekeeping in our country and these studies informations will be important for the standardization of Turkish propolis. 
Table 1. Propolis samples tested in the study.

\begin{tabular}{|c|c|c|c|c|}
\hline Sample no & $\begin{array}{l}\text { Propolis sample } \\
\text { location }\end{array}$ & $\begin{array}{l}\text { Propolis amount } \\
\text { (g) }\end{array}$ & $\begin{array}{l}\text { Propolis amount in } \\
\qquad 1 \mathrm{ml}(\mathrm{g})\end{array}$ & $\begin{array}{c}\% \text { Propolis amount } \\
(w / v)\end{array}$ \\
\hline 1 & Marmaris & 19.1 & 0.06 & 6 \\
\hline 2 & Ula & 3.2 & 0.04 & 4 \\
\hline 3 & Fethiye & 45.7 & 0.072 & 7.2 \\
\hline 4 & Milas & 105 & 0.06 & 6 \\
\hline 5 & Marmaris & 27.1 & 0.053 & 5.3 \\
\hline 6 & Datça & 4.6 & 0.13 & 13 \\
\hline 7 & Fethiye & 26.2 & 0.105 & 10.5 \\
\hline 8 & Köyceğiz & 1.5 & 0.05 & 5 \\
\hline 9 & Datça & 20.4 & 0.0071 & 0.71 \\
\hline 10 & Merkez & 2.8 & 0.06 & 6 \\
\hline 11 & Ula & 14.1 & 0.068 & 6.8 \\
\hline 12 & Bodrum & 9.5 & 0.0825 & 8.25 \\
\hline 13 & Datça & 10.7 & 0.0525 & 5.25 \\
\hline 14 & Datça & 7.3 & 0.03 & 3 \\
\hline 15 & Fethiye & 30 & 0.077 & 7.7 \\
\hline 16 & Fethiye & 12 & 0.058 & 5.8 \\
\hline 17 & Merkez & 18.3 & 0.054 & 5.4 \\
\hline 18 & Merkez & 5.8 & 0.048 & 4.8 \\
\hline 19 & Merkez & 21.9 & 0.08 & 8 \\
\hline 20 & Marmaris & 18.3 & 0.063 & 6.3 \\
\hline 21 & Milas & 10 & 0.1 & 10 \\
\hline 22 & Milas & 6.7 & 0.063 & 6.3 \\
\hline 23 & Milas & 13.4 & 0.062 & 6.2 \\
\hline 24 & Milas & 24.6 & 0.05 & 5 \\
\hline 25 & Milas & 6.5 & 0.066 & 6.6 \\
\hline 26 & Yatağan & 13.3 & 0.078 & 7.8 \\
\hline 27 & Ula & 13.8 & 0.08 & 8 \\
\hline
\end{tabular}

\section{MATERIALS AND METHODS}

\section{Propolis Samples}

227 propolis samples belonged to $A$. mellifera colonies were collected from nine areas of the Muğla city in western of Turkey, Bodrum, Datça, Fethiye, Köyceğiz, Marmaris, Merkez, Milas, Ula and Yatağan where honeydew beekeeping is practiced extensively, from September to
November in the years of between 2004 and 2006. In this study, suitable apiaries were chosen from villages. It was important that the villages are separated with enough distance and there are enough vegetation differences, which also represent Muğla statistically The samples were collected using propolis traps and stored in the freezer until further processing. 


\section{Preparation of Ethanol Extracts of Propolis (EEP)}

Propolis sample was hardened in a freezer and ground in a handy grinder. Then $100 \mathrm{~g}$ of the sample was dissolved in $300 \mathrm{ml}$ of $96 \%$ ethanol. This mixture was incubated for 4 weeks at $30^{\circ} \mathrm{C}$ in a tightly closed bottle with periodically stirring. After incubation, supernatant was filtered twice with Whatman No. 4 then with No. 1 filter papers. The final filtered solution (concentrated EEP, Table 1) was diluted in 1:10 ratio (w/v) with $96 \%$ ethanol and this solution was called EEP. For GC MS analysis, a portion of the EEP was evaporated to dryness. Then about $5 \mathrm{mg}$ of residue was mixed with $75 \mu \mathrm{l}$ of dry pyridine and $50 \mu \mathrm{l}$ bis(trimethylsilyl)trifluoroacetamide(BSTFA), heated at $80^{\circ} \mathrm{C}$ for $20 \mathrm{~min}$ and then the final supernatant was analyzed by GC-MS $[40,41]$.

\section{GC-M S (Gas Chromatography Coupled to Mass Spectrometry) Analysis}

A GC 6890N from Hewlett-Packard (Palo Alto, CA, USA) coupled with a mass detector (MS5973, Hewlett-Packard) was used for the analysis of the diluted EEP samples. Experimental conditions of the GC-MS system were as follows: a DB 5MS column $(30 \mathrm{~m} \times 0.25 \mathrm{~mm}$ and $0.25 \mu \mathrm{m}$ of film thickness) was used and flow rate of mobile phase $(\mathrm{He})$ was set at $0.7 \mathrm{~mL} / \mathrm{min}$. In the gas chromatography part, temperature was kept at $50^{\circ} \mathrm{C}$ for $1 \mathrm{~min}$. After this period, the temperature was increased to $150^{\circ} \mathrm{C}$ with a $10^{\circ} \mathrm{C} / \mathrm{min}$ heating ramp and then kept at $150^{\circ} \mathrm{C}$ for 2 min. Finally, temperature was increased to $280^{\circ} \mathrm{C}$ with a $20^{\circ} \mathrm{C} /$ min heating ramp and then kept at $280^{\circ} \mathrm{C}$ for 30 $\min [40,41]$.

\section{RESULTS AND DISCUSSION}

In this study 27 propolis samples were collected from nine areas of the Muğla city in western of Turkey. Geographical regions and some other properties of the propolis samples are listed in Table 1.

$1 \mu \mathrm{l}$ of EEP extract was injected to the GCMS system to screen the sample and identify the compounds present in each propolis sample. Compounds were identified by computer search using reference Wiley Library (HP commercial library) and mass spectra patterns.
GC-MS chemical substance analyses of 27 propolis samples revealed many chemicals including alcohols, aromatic alcohols, linear aldehydes, flavanones, linear hydrocarbons, linear acid esters, aromatic acids, aromatic esters, aromatic acid esters, aliphatic carboxilic acids, aliphatic carboxilic acid esters, aliphatic esters and other chemical substances (Table 2, Table 3).

Table 2 and Table 3 show the chemical compound results of the propolis samples.

Propolis samples dissolution rates were also different due to different compounds in ethanol that propolis samples are included. So EEP Propolis concentration changed between $0.71 \%$ and $13 \%$. If the amount of hydrophilic compounds in propolis samples are more the rate of dissolution is higher. In other words, the high flavonoid content of propolis samples depends on propolis samples high dissolution (Uzel et. al., 2005). Similarly we found in our study generally high EEP concentrations and depends on it high flavanoid content. Uzel et al., (2005) also found in their studies $0.78 \%-13.40 \%$ EEP Propolis concentration in 4 Turkish propolis.

Flavanoids are important compounds because of their antioxidant effects. Flavanones are one of the most important groups of the flavonoids. We determined 4H-1-Benzopyran-4-one, 5-hydroxy7-methoxy-2-phenyl, 4H-1-Benzopyran-4-one, 2,3-dihydro-5,7-dihydroxy-2-phenyl, $\quad 4 \mathrm{H}-1$ Benzopyran-4-one, 3,5,7-trihydroxy-2-phenyl, Chrysin and 4,5-Dihydroxy-7-methoxyflavanone as flavanones in the propolis samples. Chrysin and 4',5-dihydroxy-7methoxyflavanone (Sakuranetin) were previously found in propolis by Velikova et al., 2000. In our study the total amount of flavanones were found between 2.2\%-31\%. Güler et al., [42] has also determined the total flavanones amount in Turkish propolis between $4.72 \%-37.55 \%$.

It has been reported that propolis has antimicrobial activity because of aromatic acid esters and flavanoids [39,43,44]. Additionally it has been showed that aromatic acids and flavanoids have antiviral activity. [45-49]. We found in our study $70 \%$ as the highest amount of total aromatic acid esters and some of them 
Table 2. Chemical components of the EEP samples (\%).

\begin{tabular}{|c|c|c|c|c|c|c|c|c|c|c|c|c|c|c|}
\hline 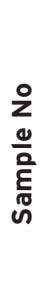 & $\begin{array}{l}\frac{n}{0} \\
\frac{0}{8} \\
\frac{u}{4}\end{array}$ & 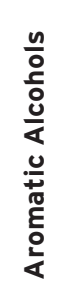 & 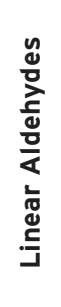 & 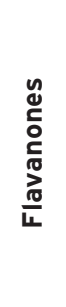 & 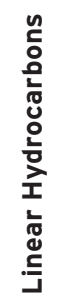 & 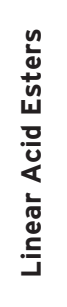 & 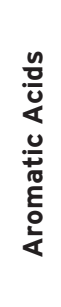 & 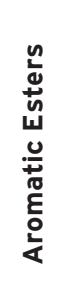 & 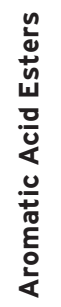 & 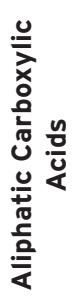 & 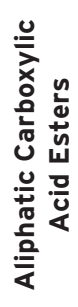 & 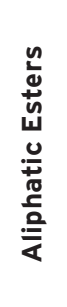 & 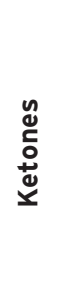 & 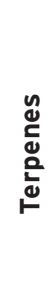 \\
\hline 1 & - & 0.4 & - & - & 1.6 & 0.5 & 0.1 & - & 70 & 0.3 & 1.4 & - & - & - \\
\hline 2 & - & - & - & 2.2 & 0.8 & 0.5 & 0.2 & - & 64 & 0.2 & 1.6 & - & - & - \\
\hline 3 & - & 1.6 & - & 17 & 0.2 & 1.3 & 0.3 & 13 & 0.5 & - & 2.1 & - & 1.0 & - \\
\hline 4 & - & 3.8 & - & 6.7 & 2.6 & 2 & - & 6.7 & - & - & 3.7 & - & - & 0.3 \\
\hline 5 & - & 0.8 & - & 12 & - & 0.7 & - & - & 51 & - & 2.9 & - & - & - \\
\hline 6 & - & 3.3 & - & 17 & - & 2.3 & - & 15 & - & - & 8.8 & - & - & - \\
\hline 7 & 0.5 & 5 & - & 28 & - & 0.4 & - & - & 18 & - & 1.2 & - & 0.5 & - \\
\hline 8 & - & 1.3 & - & - & 1.7 & 1.2 & - & - & 58 & - & 2.8 & 2.3 & - & 1.4 \\
\hline 9 & 0.4 & 2 & 0.2 & 16 & - & 0.9 & 0.4 & 13 & 1.5 & - & 2.6 & - & - & - \\
\hline 10 & - & - & - & - & 2.1 & 0.2 & - & 0.6 & 6.6 & - & 0.5 & - & - & - \\
\hline 11 & - & 0.3 & - & 13 & - & 0.4 & - & - & 38 & - & 1.8 & - & - & - \\
\hline 12 & 0.3 & 3.3 & - & 20 & 4.4 & 1.3 & 0.4 & 13 & - & - & 1.1 & - & - & 0.1 \\
\hline 13 & 0.1 & 0.4 & - & 16 & 4.4 & 1.1 & 0.2 & 7.5 & 0.2 & - & 2.1 & - & 0.9 & 0.3 \\
\hline 14 & 0.3 & 1.4 & - & 25 & 6.8 & 1.9 & - & 7 & 0.4 & - & 3.3 & - & 1 & - \\
\hline 15 & 0.1 & 0.2 & - & 9 & 2.3 & 0.6 & 0.3 & - & 51 & - & 1.7 & - & - & 0.3 \\
\hline 16 & - & 1.7 & 1.6 & 11 & 5.4 & 0.8 & 0.2 & - & 28 & - & 2.3 & - & - & 0.9 \\
\hline 17 & 0.5 & 0.4 & - & 22 & 6.7 & 1.7 & 0.2 & 9.5 & - & - & 2.6 & - & 1 & 0.3 \\
\hline 18 & - & 0.3 & - & 10 & 5.1 & 0.8 & - & - & 35 & 0.2 & 2.6 & 1 & - & - \\
\hline 19 & 0.8 & 4.8 & 0.2 & 31 & 3.5 & 0.7 & - & 6.1 & - & - & 1.3 & - & - & - \\
\hline 20 & 0.3 & 1.6 & - & 12 & 5.2 & 1.6 & - & - & 28 & - & 1.4 & - & 1.1 & - \\
\hline 21 & - & 0.1 & - & 4.4 & - & 1.3 & - & 1.6 & 13 & - & 4.1 & 1.6 & - & 0.7 \\
\hline 22 & - & 0.7 & - & 8.4 & 6.8 & 2.2 & - & 8.3 & - & - & 3.8 & - & 1.4 & 1.5 \\
\hline 23 & 0.3 & 2.4 & - & 23 & 3.9 & 0.6 & - & 9.7 & 2.3 & - & 2.9 & - & - & - \\
\hline 24 & - & 0.6 & - & 13 & 4.5 & 1.1 & - & 4.9 & - & - & 4.9 & - & - & 4.1 \\
\hline 25 & - & 1 & - & 4.4 & 3.1 & 0.9 & - & 1.2 & 23 & - & 3.2 & 3.1 & - & 1.1 \\
\hline 26 & - & 0.9 & - & 9.7 & 4.3 & 1.4 & - & 1.8 & 0.2 & - & 5.7 & 0.8 & - & 3 \\
\hline 27 & 0.1 & 1.4 & 0.9 & 20 & 4.6 & 0.7 & - & 8.7 & 7.3 & - & 3.2 & 0.7 & - & 0.2 \\
\hline
\end{tabular}




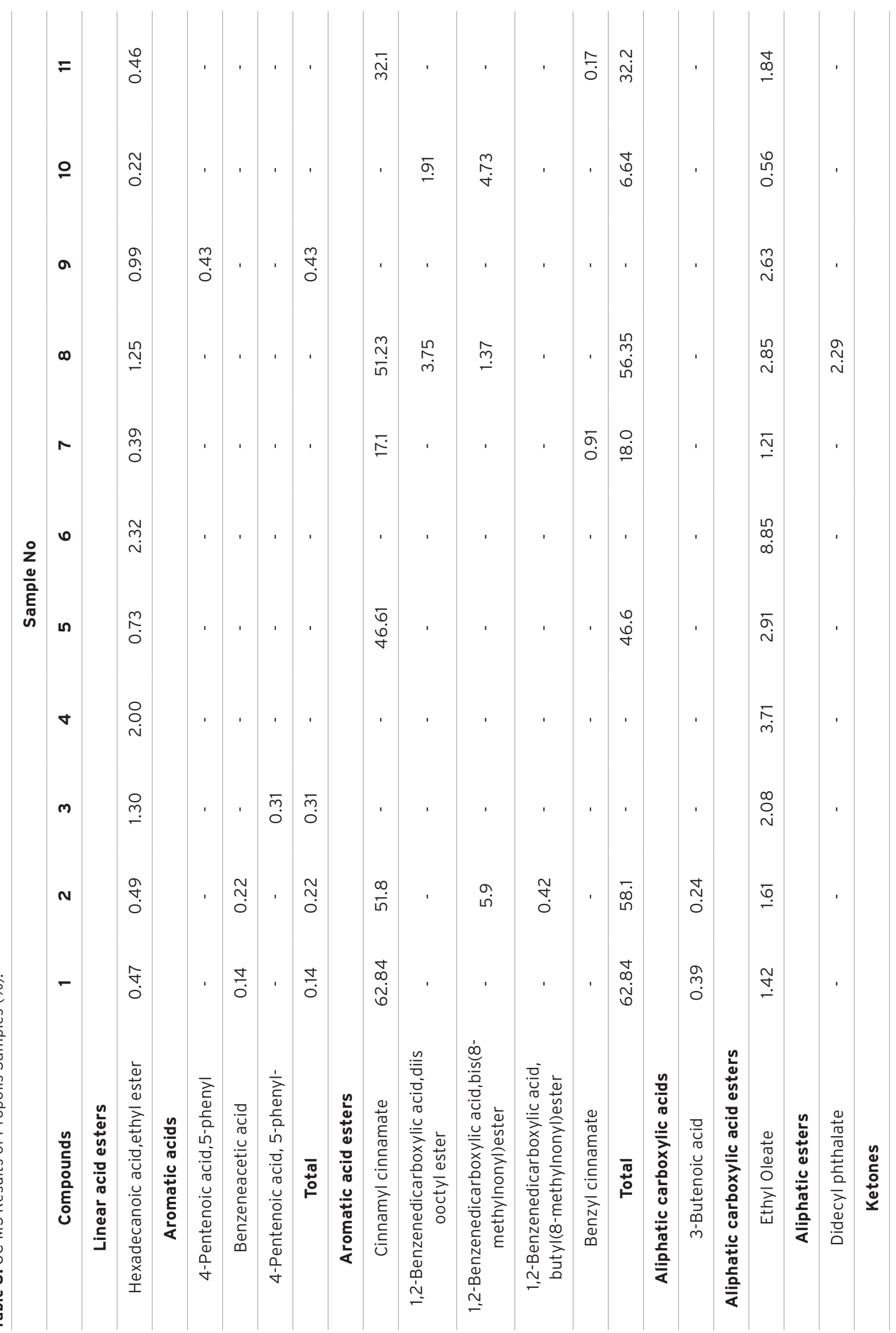




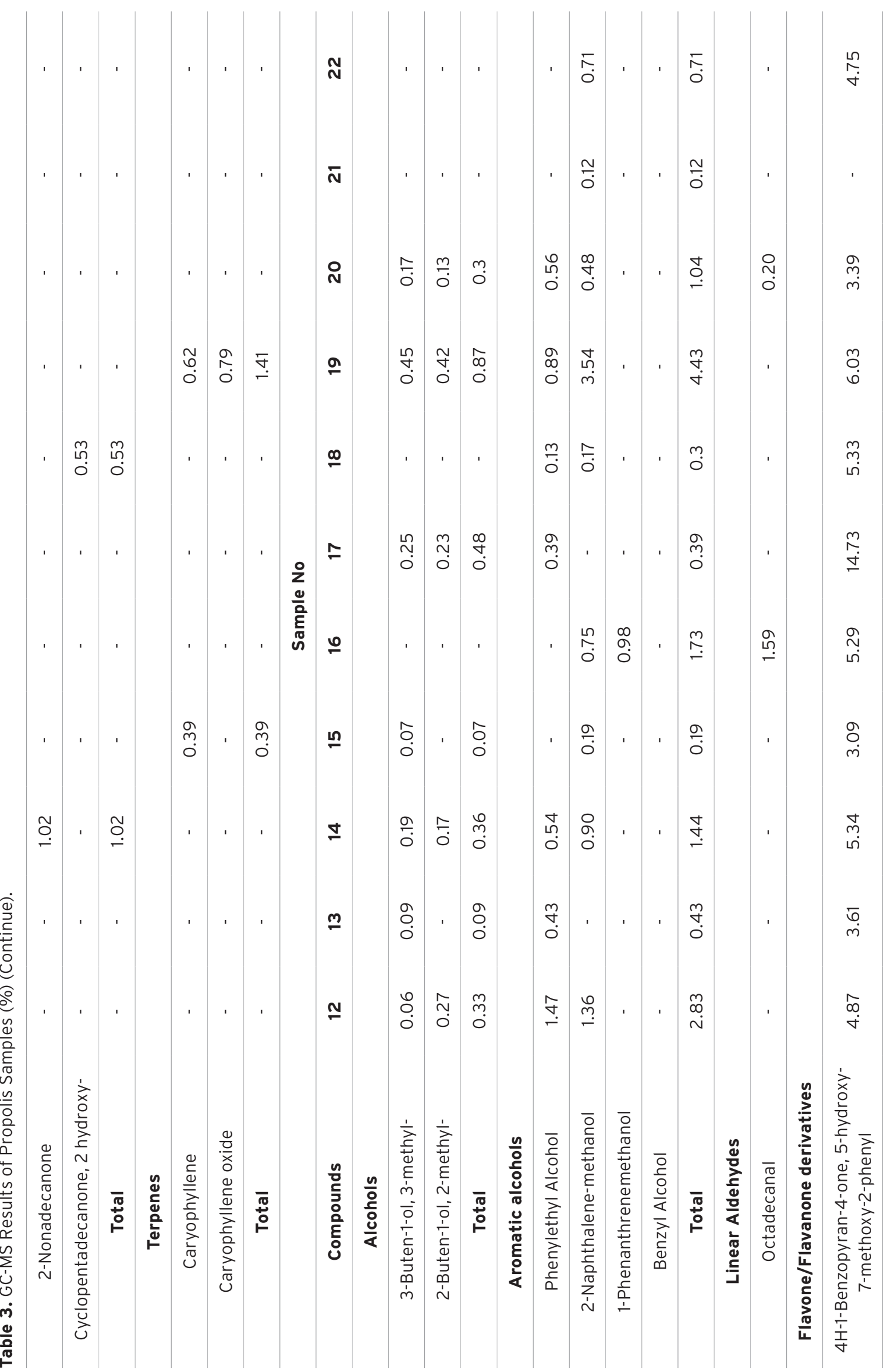




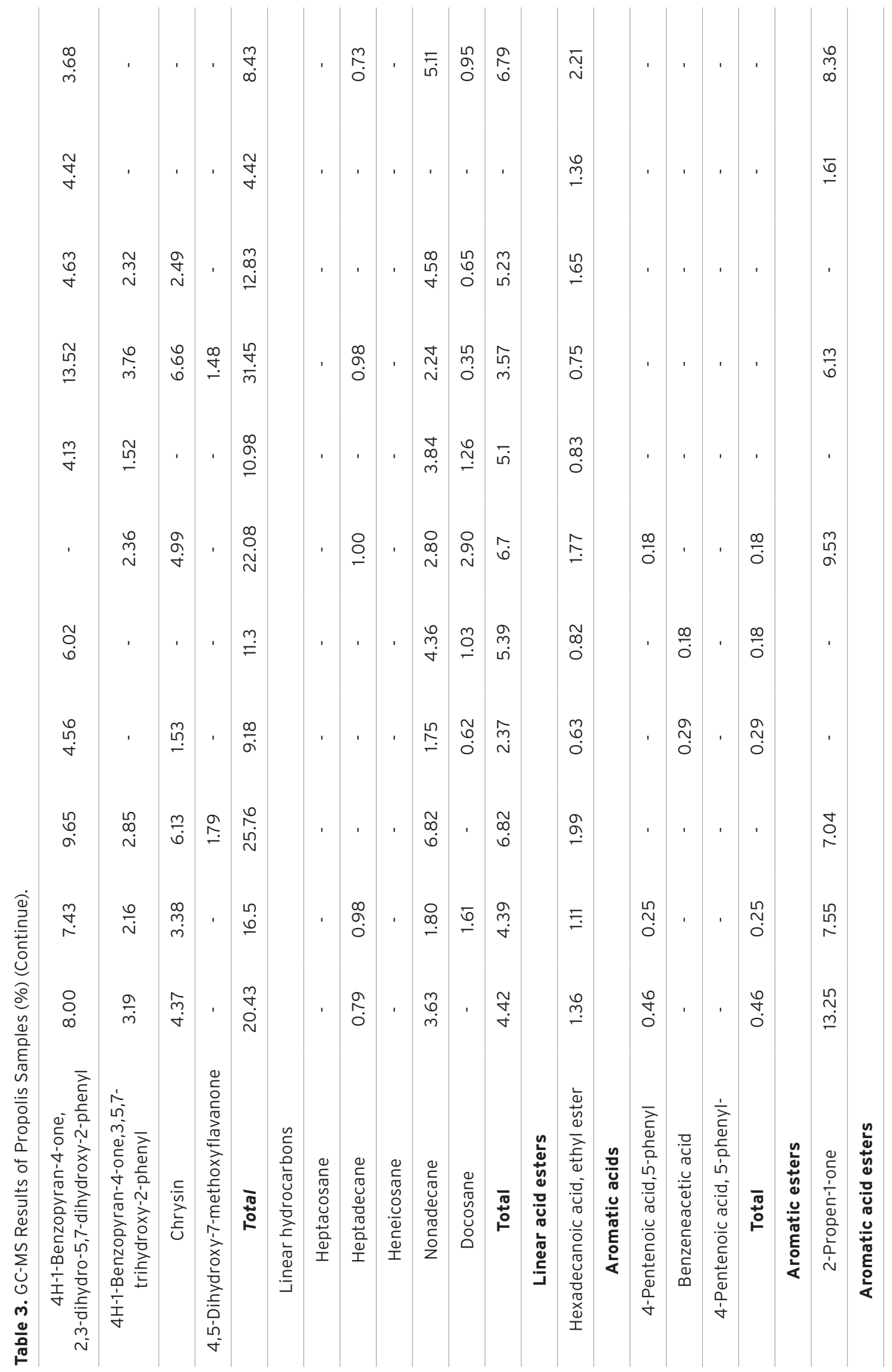


A. Özkök et al. / Hacettepe J. Biol. \& Chem., 2016, 44 (3), 327-338 | 335

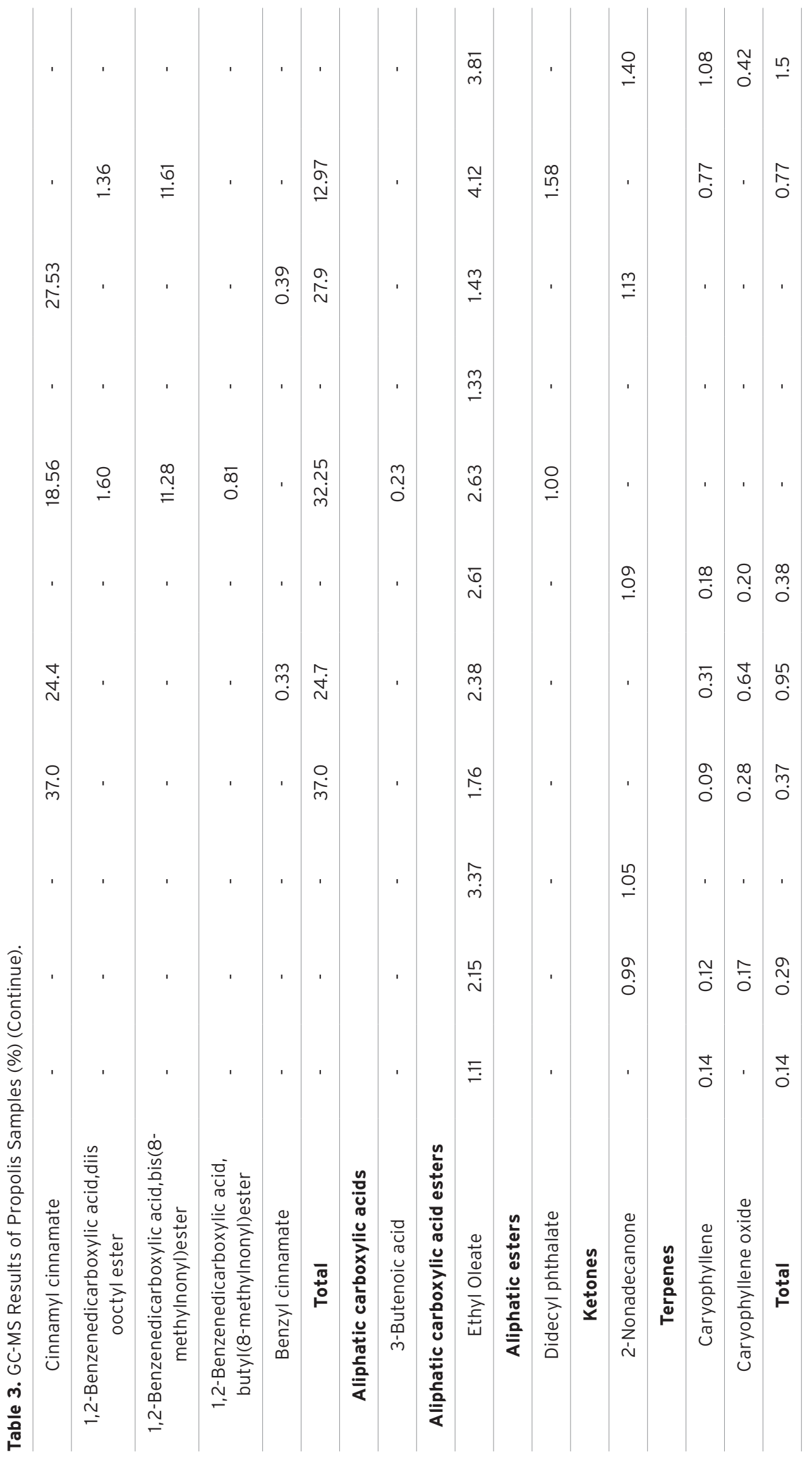


are Cinnamyl cinnamate, 1,2-Benzenedicarboxylic acid, diis ooctyl ester, 2-Benzenedicarboxylic acid bis(8-methylnonyl)ester, 2-Benzenedicarboxylic acid, butyl (8-methylnonyl)ester and Benzyl cinnamate aromatic acid esters.

Linear hydrocarbons Heptacosane, Heptadecane, Heneicosane, Nonadecane, Docosane were found in propolis samples. The total amount of linear hydrocarbons were found between 0.2\%-6.8\%. Heneicosane was before determined by Greenaway et al., 1987 [50]; Seifert and Hasslinger, 1989 [51]; Garcia-Viguera et al., 1992 [52]; Marcucci et. al., 1993 [53]. Also Docosane was found by Bankova et al., (1998) [54] in propolis samples which belongs to Canarian Islands.

Aliphatic carboxylic acids and esters were found in this study. Especially Ethyl Oleate was found in all propolis samples. Ethyl oleate is a fatty acid ester formed by the condensation of oleic acid and ethanol. It is a colorless to light yellow liquid. Ethyl oleate is used as a solvent for pharmaceutical drug preparations involving lipophilic substances such as steroids. It also finds use as a lubricant and a plasticizer [55]. Ethyl oleate has been identified as a primer pheromone in honeybees [56]. This can be the answer why we found it all propolis samples.

Ketones are simple compounds that contain a carbonyl group (a carbon-oxygen double bond). Many ketones are known and many are of great importance in industry and in biology. Examples include many sugars (ketoses) and the industrial solvent acetone. It has been found in seven of the propolis samples between 0.5\%-1.4\%. 2-Nonadecanone and 2-Hydroxycyclopentadecanone were the ketones that we found in the research.

Terpenes are a large and diverse class of organic compounds, produced by a variety of plants, particularly conifers. They are the major components of resin, and of turpentine produced from resin. Terpenes and terpenoids are the primary constituents of the essential oils of many types of plants and flowers. Caryophyllene and Caryophyllene oxide were found in some propolis samples as terpenes between $0.1 \%-1.5 \%$.

\section{CONCLUSIONS}

In this study some propolis findings were found about in the western region of Turkey. Regional propolis data is very important for countries because of the international standard of the propolis. These informations can use preparation of the general propolis standard in the future.

\section{ACKNOWLEDGEMENTS}

We are indebted to the The Scientific and Technological Research Council of Turkey (TÜBITAK) for financial support, and also to Muğla Beekeepers' Association (MAYBiR) and local people who helped us during our fieldwork.

\section{References}

1. V.D. Wagh, Propolis: a wonder bees product and its pharmacological potentials, Adv. Pharm. Sci., 2013 (2013) 308249.

2. V. Bankova, M. Popova, S. Bogdanov, A.G. Sabatini, Chemical composition of European propolis: expected and unexpected results. Z Naturforsch., 57 (2002) 530-533.

3. S. Castaldo, F. Capasso, Propolis, an old remedy used in modern medicine. Fitoterapia, 73 (2002) 1-6.

4. L. Monzote, O. Cuesta-Rubio, M. Campo Fernandez, I. Márquez Hernandez, J. Fraga, K. Pérez, M. Kerstens, L. Maes, P. Cos, In vitro antimicrobial assessment of Cuban propolis extracts. Mem. Inst. Oswaldo Cruz, 107 (2012) 978-984.

5. H. Shi, H. Yang, X. Zhang, L. Yu, Identification and quantification of phytochemical composition and anti-inflammatory and radical scavenging properties of methanolic extracts of Chinese propolis. J. Agr. Food Chem., 60 (2012) 12403-12410.

6. G.C. Chan, K.W Cheung, D.M. Sze, The immunomodulatory and anticancer properties of propolis. Clin. Rev. Allergy Immunol., 44 (2013) 262273.

7. M.I. Nieva Moreno, M.I. Isla, N.G. Cudmani, M.A. Vattuone, A. R. Sampietro, Screening of antibacterial activity of Amaicha del Valle (Tucumán, Argentina) própolis . Ethnopharmacol, 68 (1999) 97-102.

8. O. Koru, F. Toskay, C.H. Açıkel, Y.M. Tunca, M. Baysallar, G.A. Üsküdar, E. Akça, A. Özkök Tüylü, K. Sorkun, M. Tanyüksel, B. Salih, In vitro antimicrobial activity of propolis samples from different geographical origins against certain oral pathogens, Anaerobe, 13,3-4 (2007) 140-145.

9. N. Vera, E. Solorzano, R. Ordóñez, L. Maldonado, E. Bedascarrasbure, M.I. Isla Chemical composition of Argentinean propolis collected in extreme regions and its relation with antimicrobial and antioxidant activities, Nat Prod. Commun., 6 (2011) 823-827. 
10. E. Solorzano, N. Vera, S. Cuello, R. Ordóñez, C. Zampini, L. Maldonado, E. Bedascarrasbure, M.I. Isla Chalcones in bioactive argentine propolis collected in arid environments Nat. Prod. Commun., 7 (2012) 879-882.

11. A.L. Salas, R.M. Ordóñez, C. Silva, L. Maldonado, E. Bedascarrasbure, M.I. Isla, I.C. Zampini, Antimicrobial activity of Argentinean propolis against Staphylococcus isolated of canine otitis J. Exp. Biol. Agric. Sci., 2 (2014) 197-207.

12. M.B. Agüero, M. González, B. Lima, L. Svetaz, M. Sánchez, S. Zacchino, G. Feresin, G. SchmedaHirschmann, J. Palermo, D. Wunderlin, A. Tapia Argentinean propolis from Zuccagnia punctata Cav. (Caesalpiniceae) exudates: phytochemical characterization and antifungal activity J. Agric. Food Chem., 58 (2010) 194-201.

13. M.I. Isla, M.I. Nieva Moreno, C. Zampini, E. Solórzano, C. Danert, A. Salas, N. Vera, J. Sayago, E. Bedascarrasbure, L. Maldonado, R. Ordóñez Argentine propolis: flavonoid and chalcone content and its relation with the functional properties $T$. Farroqui, A.A. Farooqui (Eds.), Beneficial Effects of Propolis on Human Health and Chronic Diseases, Nova Science Publishers, Hauppauge (New York) (2013) 161-170.

14. M.I. Nieva Moreno, I.C. Zampini, M. Ordóñez, M.A. Vattuone, M.I. Isla Evaluation of the cytotoxicity, mutagenicity and antimutagenicity of propolis from Amaicha del Valle, Tucumán, Argentina J. Agric. Food Chem., 53 (2005) 8957-8962.

15. 15. F.C. Danert, C. Zampini, R. Ordóñez, L. Maldonado, E. Bedascarrasbure, M.I. Isla Argentinean propolis as non-conventional functional foods Nutr. Funct. Compos. Nat. Prod. Commun., 9 (2014) 167-170.

16. Y. Barlak, O. Deger, M. Colak, S.C. Karatayli, A.M. Bozdayi, F. Yucesan, Effect of Turkish propolis extracts on proteome of prostate cancer cell line Proteome Science, 9 (2011) 74.

17. G.C. Chan, K.W. Cheung, D.M. Sze, The immunomodulatory and anticancer properties of propolis Clin Rev Allergy Immunol, 44 (2013) 262-273.

18. M. Lofty, Biological activity of bee propolis in health and disease Asian Pacific Journal of Cancer Prevention, 7 (2006) 22-31.

19. S. Umthong, P. Phuwapraisirisan, S. Puthong, C. Chanchao In vitro antiproliferative activity of partially purified Trigona laeviceps propolis from Thailand on human cancer cell lines BMC Complementary and Alternative Medicine, 11 (2011) 37.

20. M.J. Valente, A.F. Baltazar, R. Henrique, L. Estevinho, M. Carvalho Biological activities of Portuguese propolis: Protection against free radical-induced erythrocyte damage and inhibition of human renal cancer cell growth in vitro Food and Chemical Toxicology: An International Journal Published for the British Industrial Biological Research Association, 49 (2011) 86-92.

21. Wu, C. Omene, J. Karkoszka, M. Bosland, J. Eckard, C.B. Klein, K. Frenkel Caffeic acid phenethyl ester (CAPE), derived from a honeybee product propolis, exhibits a diversity of anti-tumor effects in pre-clinical models of human breast cancer Cancer Letters, 308 (2011) 43-53.
22. H. Fokt, A. Pereira, A.M. Ferreira, A. Cunha, C. Aguiar How do bees prevent hive infections? The antimicrobial properties of propolis A. Mendez-Vilas (Ed.), Current Research, Technology and Education Topics in Applied Microbiology and Microbial Biotechnology, vol. 1 Formatex, Badajoz, Spain (2010) 481-493 Microbiology Book Series- Number 2.

23. A. Salatino, C.C. Fernandes-Silva, A.A. Righi, M.L.F. Salatino, Propolis research and the chemistry of plant products. Nat. Prod. Rep., 28 (2011) 925-936.

24. V.A. Tagliacollo, R.O. Orsi, Quality of propolis commercialized in the informal market. Ciênc. Tecnol. Aliment., 31 (2011) 752-757.

25. I.M. Hernández, O. Cuesta-Rubio, M.C. Fernández, A.R. Pérez, R.M. Oca Porto, A.L. Piccinelli, L. Rastrelli, Studies on the constituents of yellow Cuban Propolis: GC-MS determination of triterpenoids and flavonoids. J. Agr. Food Chem., 58 (2010) 4725-4730.

26. T. Farooqui, A.A. Farooqui, Beneficial effects of propolis on human health and neurological diseases. Front. Biosci., 4 (2012) 779-793.

27. V. Bankova, M.C. Marcucci, S. Simova, N. Nikolova, A. Kujumgiev, S. Popov, Antibacterial diterpenic acids from Brazilian propolis. Z. Naturforsch. C., 51 (1996) 277-280.

28. V. Bankova, Chemical diversity of propolis and the problem of standardization. J. Ethnopharmacol., 100 (2005) 114-117.

29. R. Silva-Carvalho, V. Miranda-Gonçalves, A. Margarida Ferreira, S. M. Cardoso, A. J.F.N. Sobral, C. AlmeidaAguiar, F. Baltazar, Antitumoural and antiangiogenic activity of Portuguese propolis in in vitro and in vivo models, Journal of Functional Foods, 11 (20149) 160171.

30. D. Kasote, T. Suleman, W. Chen, M. Sandasi, A. Viljoen, S. Vuuren, Chemical profiling and chemometric analysis of South African Propolis, Biochemical Systematics and Ecology, 55 (2014) 156-163.

31. K. Sorkun, S. Bozcuk, Investigation of the effect of propolis on seed germination of some culture plants. X II. National Biology Conf. Edirne, Turkey, (1994), 54 -59 .

32. H. Orhan, S. Marol, I.F. Hepsen, G. Sahin, Effect of some probable antioxidants on selenite-induced cataract formation and oxidative stress-related parameters in rats. Toxicology, 139 (1999) 219-232.

33. K. Ozturk, E. Kurt, M. Cerci, I. Emiroglu, U.U. Inan, S.S. Ilker, The effect of propolis extract in experimental chemical corneal injury. Ophthalmic Res., 32 (2000) 13-18.

34. M. Velikova, V. Bankova, K. Sorkun, S. Haucine, I. Tsvetkova, A. Kujumgiev, Propolis from Mediterraneaen region: Chemical composition and antimicrobial activity. Z. Naturforsch., 55 (2000) 1-4 .

35. M. Velikova, V. Bankova, K. Sorkun, S. Popov, E. Kujumgiev, Chemical biological activity of propolis from Turkish and Bulgarian origin. Mellifera, 1 (2001) $57-59$.

36. D. Kolankaya, G. Selmanoğlu, K. Sorkun, B. Salih, Protective effects of Turkish propolis on alcoholinduced serum lipid changes and liver injury in male rats, Food Chemistry, 78 (2002) 213-217. 
37. G. Girgin, T. Baydar, M. Ledochowski, H. Schennach, D.N. Bolukbası, K. Sorkun, B. Salih, G. Sahin, D. Fuchs, Immunomodulatory effects of Turkish propolis: Changes in neopterin release and tryptophan degradation, Immunobiology, 214 (2009) 129-134.

38. S. Vatansever, K. Sorkun, D.i. Gurhan, O.F. Kurt, E. Turkoz, O. Gençay, B. Salih, Propolis from Turkey induces apoptosis through activating caspases in human breast carcinoma cell lines, Acta Histochemica, 112 (2010), 546-556.

39. A. Temiz, A. Sener, A. Özkök Tüylü, K. Sorkun, B. Salih Antibacterial activity of bee propolis samples from different geographical regions of Turkey against two foodborne pathogens, Salmonella Enteritidis and Listeria monocytogenes, Turkish Journal Biology, 35 (2011) 503-511.

40. N. Cihangir, K. Sorkun, B. Salih, Chemical composition and antibacterial activities of propolis collected from different regions of Turkey. Hacettepe Journal of Biology and Chemistry, 34 (2005) 59-67.

41. A. Uzel, K. Sorkun, Ö. Önçağ, Chemical compositions and antimicrobial ativities of four different Anatolian propolis samples. Microbiol. Res., 160 (2005) 189-195.

42. P. Güler, K. Sorkun, B. Salih, Effect of some Turkish Propolis on the product quantity of Agaricus bisporus (Lange.) Sing, Pak. J. Bot., 35 (2003) 439-447.

43. E. Debuyser, La propolis. Docteur en Pharmacie Thesis, Universite de Nantes, France, (1983) 82.

44. L. Meresta, T. Meresta, Antibacterial activity of flavanoid compounds of propolis, occurring in flora in Poland. Bull Vet Inst Pulawy 28-29, 61-63, Apic Abstr (1990) 41, 1345.

45. A. Helbig, K.D. Thiel, Comparison of the antiviral activity of oxidizing caffeic acid and hydrocaffeic acid against Herpesvirus hominis types 1 and 0 in vitro. Pharmazie, 37 (1982) 603-604.

46. H. Ishitsuka, C, Ohsawa, T. Ohiwa, I. Umeda, Y. Suhara, Antipicornavirus flavone RO-09-0179. Antimicrob Agents Chemother, 22 (1982) 611-616.
47. I. Mucsi, Combined antiviral effect of flavanoids and 5-ethyl-2'-deoxyuridineon the multiplication of herpes virus. Acta Virol., 28 (1984) 395-400.

48. R. Vrijien, L. Everaet, A. Boeye, Antiviral activity of flavones and potentiation by ascorbate, J. Gen. Virol., 69 (1988) 1749-1753.

49. M. Amoros, E. Lurton, J. Boustie, L. Girre, F. Sauvager, M. Cormier, Comparison of the anti-herpes simplex virus activities of propolis and 3-methylbut-2-enyl caffeate. J. Nat. Prod., 57 (1994) 644-647.

50. W. Greenaway, T. Scaysbrook, F.R. Whatley, The analysis of bud exudate of Populus $x$ euramericana, and of propolis, by gas chromatography-mass spectrometry. Proc. R. Soc(Lond) Ser. B, 232 (1987) 249-272.

51. M. Seifert, E. Haslinger, Über die Inhaltsstoffe der Propolis. I. Liebigs Ann Chem, (1989) 1123-1126.

52. C. Garcia-Viguera, W. Greenaway, F.R. Whatley, Composition of propolis from two different Spanish regions. Z. Naturforsch, 47 (1992) 634-637.

53. M.C. Marcucci, M.L.F. Salatino, A. Salatino, Propolis constituents: waxes. Proc. SIMCRO(Brazilian Symposium of Chromatography), FM Lanças, Aguas de Sao Pedro, Brazil (1993) 37.

54. V.S. Bankova, R.S. Christov, A.D. Tejera, Lignans and other constituents of propolis from the Canary Islands, Phytochemistry, 49 (1998) 1411-1415.

55. S.J. Ory, C.B. Hammond, S.G. Yancy, R.W. Hendren, C.G Pitt, The effect of a biodegradable contraceptive capsule (Capronor) containing levonorgestrel on gonadotropin, estrogen, and progesterone levels. Am. J. Obstet. Gynecol., 145 (1983) 600-5.

56. I. Leoncini, Y. Le Conte, G. Costagliola, E. Plettner, A.L. Toth, M. Wang, Z. Huang, J.M. Bécard, Regulation of behavioral maturation by a primer pheromone produced by adult worker honey bees, Proc. Natl. Acad. Sci. U.S.A., 101 (2004) 17559-17564. 